\title{
Nephritic Factor of the Classical
}

\section{Pathway of Complement}

\section{IMMUNOGLOBULIN G AUTOANTIBODY DIRECTED AGAINST THE}

\author{
CLASSICAL PATHWAY C3 CONVERTASE ENZYME
}

\author{
L. Halbwachs, M. Leveillé, Ph. Lesavre, S. Wattel, and J. Leibowitch, \\ Département de Néphrologie et Institut National de la Santé et de la Recherche \\ Médicale U 25, Groupe de Recherche sur le Complément en Pathologie \\ Humaine, Hopital Necker, 75015 Paris, France
}

\begin{abstract}
A B S T R A C T A factor, functionally characterized by its capacity to stabilize the normally labile classical pathway C3-converting complex of the classical pathway of complement, has been isolated from the serum of one patient with a case of acute glomerulonephritis, subsequent to a cutaneous infection. The factor confers long-lived stabilization of classical pathway C3 convertase complexes formed both in the solid (sensitized sheep erythrocytes bearing activated $\overline{\mathrm{Cl}}$ and the classical pathway C3 convertase) and fluid phase. The halflife of such stabilized C3-cleaving enzymes extended beyond several hours at $37^{\circ} \mathrm{C}$. The stabilizing activity was associated with a protein fraction immunochemically identified as immunoglobulin (Ig)G, a sizeable population of which exhibited a gamma chain of 60,000 daltons. The IgG-associated stabilizing activity was found to bind to the classical pathway C3 convertase enzyme via a fragment bearing the antigen-binding site of the molecule $\left[\mathrm{F}(\mathrm{ab})_{2}\right.$ and $\left.\mathrm{F}(\mathrm{ab})\right]$. Such binding was demonstrable for classical pathway and not for altemative pathway C3 convertase. Thus, the stabilizing factor behaves like an autoantibody to the C3-converting complex of the classical pathway of complement. The binding of the antibody to the enzyme affords protection of the latter against decay-degradation. By analogy with the nephritic factor of the alternative pathway situation where IgG autoantibodies specifically bind to alternative pathway C3 convertase
\end{abstract}

This work was presented in part at the Société Française de Néphrologie (May 1979), and at the Eighth International Complement Workshop (October 1979).

Dr. Leveille was the recipient of a grant from the Collège de Médicne des Hôpitaux de Paris.

Received for publication 14 September 1979 and in revised form 27 November 1979. enzymes and protect them from degradation, the functionally unusual IgG in our patient was designated as the nephritic factor of the classical pathway. Indirect evidence suggests that nephritic factor of the classical pathway-IgG might be of the IgG3 subclass.

\section{INTRODUCTION}

The complement system schematically comprises two major enzymatic complexes, both endowed with similar cleaving functions on the third (C3) and the fifth (C5) native complement proteins.

These C3/C5 convertases differ in their molecular composition according to the events that have initiated their formation: (a) Immune complexes, which activate the first component, $\mathrm{Cl}$, will lead to the formation of a classical pathway C3/C5 convertase, consisting in the active forms of the fourth and the second components bound together as classical pathway $\mathrm{C} 3$ convertase $(\mathrm{C} \overline{\mathrm{4b2a}})^{1}$ complexes (1). (b) "Activators" of the alternative pathway will allow factor B and C3 to form alternative pathway $\mathrm{C} 3$ convertase $(\mathrm{C} \overline{\mathrm{bBb}})$ complexes endowed with C3/C5 convertase activity (2).

Both classical and alternative pathway bimolecular convertases are subjected in serum to potent homeo-

\footnotetext{
${ }^{1}$ Abbreviations used in this paper: $\beta-1 \mathrm{H}, \beta-1 \mathrm{H}$ globulin; $\mathrm{C} \overline{3 \mathrm{bBb}}$, alternative pathway $\mathrm{C} 3$ convertase; $\mathrm{C} \overline{4 \mathrm{~b} 2 \mathrm{a}}$, classical pathway $\mathrm{C} 3$ convertase; DGVB, dextrose gelatin veronal buffer; DGVB ${ }^{++}$, DGVB containing calcium and magnesium; EAC $\overline{14 b 2 a}$ sensitized sheep erythrocytes bearing activated $\mathrm{Cl}$ and the complex $\mathrm{C} \overline{4 \mathrm{~b} 2 \mathrm{a}}$; EAC $\overline{3 \mathrm{bB}}$, sensitized sheep erythrocytes bearing the complex $\mathrm{C} \overline{\mathrm{BbBb}} ; \mathrm{NF}_{\mathrm{A}}, \mathrm{Ne}-$ phritic factor of the alternative pathway; $N F_{C}, N F$ of the classical pathway; NHS, normal human serum; PBS, phosphate-buffered saline; SDS-PAGE, sodium dodecyl sulfate polyacrylamide gel electrophoresis.
} 
static control, and will only acquire an efficient C5 cleaving activity provided: $(a)$ the respective $\mathrm{C} \overline{\mathrm{b} 2 \mathrm{a}}$ and $\mathrm{C} \overline{\mathrm{3bBb}}$ complexes are deposited and/or formed on a suitable solid surface, and not if they are present in a "fluid-phase" form $(3,4)$. (b) the complexes are not degraded by intrinsic decay dissociation and/or by the action of control proteins (5). These are the $\mathrm{C} 4$ binding protein $(6)$, the $\beta \mathrm{IH}$ globulin $(\beta \mathrm{IH})$ $(7,8)$, and the $\mathrm{C} 3 \mathrm{~b}$ inactivator, which inactivates both C3b $(9,10)$ and C4b (11).

The nephritic factor of the alternative pathway of complement $\left(\mathrm{NF}_{\mathrm{A}}\right)$ was first reported in 1969 (12) in a patient with chronic glomerulonephritis, and described as a factor that would lead to the formation of a fluid-phase, magnesium-dependent C3-cleaving enzyme when added to normal human serum. Over the next decade the occurrence of this factor was unequivocally established in dense deposit disease membranoproliferative glomerulonephritis (type II) (13) and partial lipodistrophy $(14,15)$.

$\mathrm{NF}_{\mathrm{A}}$ has been identified as an autoantibody specifically directed against the $\mathrm{C} \overline{\mathrm{bBb}}$ enzyme, (16-19) which confers a prolonged half-life upon this labile complex. The enhanced longevity of $\mathrm{NF}_{\mathrm{A}}$ stabilized $\mathrm{C} \overline{\mathrm{bBb}}$ complex is caused by retardation of $\mathrm{Bb}$ factor $\mathrm{B}$ release from the complex and protection against $\beta 1 \mathrm{H}$-mediated accelerated decay dissociation $(20,21)$.

The existence of an analogue in the classical pathway for the $\mathrm{NF}_{\mathrm{A}}$ has not yet been reported.

In this paper, we describe a serum factor functionally characterized by its unique capacity to stabilize C $\overline{4 \mathrm{~b} 2 \mathrm{a}}$ complexes in both solid and fluid phase. This factor is indistinguishable from immunoglobulin (Ig)G, and it is shown to act as an antibody. It was isolated from the serum of a patient with a case of acute postinfectious glomerulonephritis.

\section{METHODS}

Buffers and reagents. Isotonic phosphate-buffered saline (PBS), $\mathrm{pH} \mathrm{7.2;} \mathrm{half} \mathrm{isotonic} \mathrm{veronal-buffered} \mathrm{saline,} \mathrm{pH} \mathrm{7.2,}$ containing $2.5 \%$ dextrose, $0.5 \mathrm{mM}$ magnesium, $15 \mathrm{mM}$ calcium, and $0.1 \%$ gelatin $\left(\mathrm{DGVB}^{++}\right)$; the same buffer containing EDTA 0.02 M (DGVB-EDTA); CM-cellulose (Whatmann Biochemicals, Ltd., Maidstone, Kent, England); Sephadex G-100 and G-200, CNBr-activated Sepharose 4B (Pharmacia Fine Chemical, Ltd., Uppsala, Sweden); Papain (Boehringer, Mannheim, West Germany); Pepsin (Sigma Chemical Co., St. Louis, Mo.); and human purified IgG (Centre de Transfusion Sanguine, Paris, France).

\section{Sera}

R.A.M. serum. The studies to be reported were performed on serum and EDTA plasma from a patient (R.A.M.) with postinfectious acute glomerulonephritis. The case summary and the complement profile are reported elsewhere (22). In brief, patient R.A.M. presented acute glomerulonephritis after a protracted cutaneous infection (impetiginized scabies), all of which subsided in 6 wk. Low C3 and low C5 were the main serological abnormalities together with the finding of a circulating C3 cleaving complex. All the blood samples obtained from the patient contained similar levels of stabilizing factor.

Normal human serum (NHS). This was a pool obtained from normal healthy blood donors. Normal and patient's sera were separated after clotting $2 \mathrm{~h}$ at room temperature, and kept frozen at $-80^{\circ} \mathrm{C}$.

C2-deficient serum. These sera were obtained from patients with demonstrated homozygous C2 deficiency.

Purified components. Purified C $\overline{\mathrm{ls}}$, the enzymatically active subcomponent of $C \bar{l}$, was obtained by the method of Takahashi et al. (23). Purified C4 was kindly donated by Dr. M. G. Colomb, Laboratoire de Biochimie, Centre d'Études Nucléaires, Grenoble, France. C2 was purified by the method of Kerr and Porter (24) in which the CNBr-Sepharose step was replaced by a chromatography on CM-cellulose in $0.01 \mathrm{M} \mathrm{PO}_{4} 0.005 \mathrm{M}$ EDTA, pH 5.9. C2 hemolytic activity was titrated according to Lachmann et al. (25). In our conditions, a normal human serum pool contains $2.5 \times 10^{4} \mathrm{C} 2$ hemolytic U/ml. Factor B and factor D were purified according to Lachmann et al. (25) and Lesavre et al. (26), respectively.

$\mathrm{NF}_{\mathrm{A}}$ was purified according to Daha et al. (21) from the serum of one patient with membranoproliferative glomerulonephritis (type II).

Preparation of EAC $\overline{14 b 2 a}$. EAC $\overline{14 b}$, sensitized sheep erythrocytes bearing activated $\mathrm{C} 1$ and $\mathrm{C} 4$ were prepared as described by Lachmann et al. (25); $25 \times 10^{8} \mathrm{EA}$ in $\mathrm{DGVB}^{++}$ were incubated with $400 \mu \mathrm{l}$ of C2-deficient serum for $30 \mathrm{~min}$ at $37^{\circ} \mathrm{C}$, then washed several times in $\mathrm{DGVB}^{++}$. EAC $\overline{14 \mathrm{~b} 2 \mathrm{a}}$ were prepared by incubating $10^{9} \mathrm{EAC} \overline{14 \mathrm{~b}}$ with 2,000 hemolytic $\mathrm{U}$ of $\mathrm{C} 2$ for $5 \mathrm{~min}$ at $30^{\circ} \mathrm{C}$ in $2 \mathrm{ml} \mathrm{DGVB}{ }^{++}$. They were immediately used for the stabilization assay.

EAC $\overline{14 b 2 a}$ stabilization assay. $200 \mu \mathrm{l}$ of EAC $\overline{14 \mathrm{~b} 2 \mathrm{a}}$ cells $\left(5 \times 10^{8} / \mathrm{ml}\right)$ in $\mathrm{DGVB}^{++}$were mixed with $50 \mu \mathrm{l}$ of twofold dilutions of the patient's serum, starting at $1 / 10$, or dilutions of the purified factor in DGVB-EDTA $0.02 \mathrm{M}$, and incubated for $30 \mathrm{~min}$ at $37^{\circ} \mathrm{C}$. $10 \mu \mathrm{l}$ of normal guinea pig serum were then added as a source of C3-C9 and, after further incubation at $37^{\circ} \mathrm{C}$ for $1 \mathrm{~h}$, the reaction was stopped by the addition of $2 \mathrm{ml}$ cold $\mathrm{DGVB}^{++}$. After centrifugation, lysis was measured by $O D$ at $415 \mathrm{~nm}$. The amount of lysis was expressed as a percentage of a control exhibiting maximal C $\overline{4 b 2 a}$ hemolytic sites $(100 \%)$. We defined one "stabilizing unit" as the amount of R.A.M. serum or purified fractions maintaining $50 \%$ of the maximal $\mathrm{C} \overline{4 \mathrm{~b} 2 \mathrm{a}}$ sites in the face of a challenge decay of $30 \mathrm{~min}$ at $37^{\circ} \mathrm{C}$.

$E A C \overline{3 b B b}$ stabilization assay. It was performed according to Daha et al. (21).

Antisera. Monospecific goat antisera to human C3, factor B, and alpha 1 antitrypsin (Atlantic antibodies, Westbrook, Maine), rabbit anti-human IgG, IgA (Behringwerke, AG, Marburghone, West Germany). Rabbit anti-IgA antiserum was made monospecific by adsorption on glutaraldehyde insolubilized IgA-deficient serum (27). Goat anti-Fc gamma antiserum was a gift of Dr. Druet, INSERM U 28, Hôpital Broussais, Paris.

Purification of the $C \overline{4 \overline{b 2 a}}$ stabilizing activity. The first steps consisted of an euglobulin precipitation by dialysis against $\mathrm{PO}_{4} 5 \mathrm{mM}$, EDTA $2.5 \mathrm{mM}$, pH 5.9, and filtration of the supernate on a CM-cellulose in the same buffer. The stabilizing activity, was eluted with a linear salt gradient between 7 and $14 \mathrm{mmhos} / \mathrm{cm}$. In other preparations DEAE-cellulose was used, equilibrated with $\mathrm{PO}_{4} 0.02 \mathrm{M}, \mathrm{pH}$ 7.0. The C $\overline{4 \mathrm{~b} 2 \mathrm{a}}$ stabilizing activity came out in the exclusion peak, together with IgG.

G-200 chromatography. After concentration, the CMcellulose active pool $(7 \mathrm{ml})$ was applied to a $2.5 \times 100-\mathrm{cm}$ 
Sephadex G-200 column in PBS. IgG elution was followed by electroimmunodiffusion after carbamylation of samples of each fraction (28). The column had been precalibrated with normal human serum and the elution positions of $\mathrm{IgG}$, factor $B$ and alpha 1 antitrypsin determined by electroimmunodiffusion.

Adsorption on anti-Ig immunoadsorbents. The monospecific (affinity chromatography) antibodies were insolubilized on CNBr-4B Sepharose as described (29). The immunoadsorption of the G-200 active pool was carried out according to Davis et al. (15). The adsorbed material was eluted with $4 \mathrm{M} \mathrm{MgCl}_{2}, \mathrm{pH} 6.8$, and immediately dialyzed against PBS. After concentration to the initial volume, both the excluded and the eluted fractions were tested for IgG or IgA by electroimmunodiffusion after carbamylation, and for EAC $\overline{14 b 2 a}$ stabilizing activity.

Pepsin digestion. This was carried out according to Lachmann et al. (30): $1 \mathrm{ml}$ of $\mathrm{NF}_{\mathrm{C}}(\mathrm{G}-200 \mathrm{pool})$ at $4.5 \mathrm{mg} / \mathrm{ml}$ was incubated for $2 \mathrm{~h}$ at $37^{\circ} \mathrm{C}$ and $\mathrm{pH} 3.0$ with $0.18 \mathrm{mg}$ pepsin, and after neutralization, applied to a $1.5 \times 60-\mathrm{cm}$ precalibrated G-100 Sephadex column. The concentrated protein peak did not react with anti-Fc on Ouchterlony. Normal IgG at the same concentration were treated in the same way as a control. Another control was obtained by incubating $\mathrm{NF}_{\mathrm{c}}$ at $37^{\circ} \mathrm{C}$ and $\mathrm{pH} 3.0$, as described above, but without pepsin.

Papain digestion. This was performed in the absence of cystein, as described by Swanworth and Turner (31);1 ml of $\mathrm{NF}_{\mathrm{C}}(2.5 \mathrm{mg} / \mathrm{ml})$ was incubated with $25 \mu \mathrm{g}$ papain in PBS (EDTA $0.002 \mathrm{M}$ ) for $4 \mathrm{~h}$ at $30^{\circ} \mathrm{C}$. The reaction mixture was then applied to an anti-Fc Sepharose immunoadsorbent. The exlcusion peak and the $\mathbf{M g C l}_{2}$ eluted peak were concentrated to the initial volume and tested for stabilizing activity. As for the pepsin digestion, a control was made with normal IgG treated in the same way.

Sodium dodecyl sulfate polyacrylamide gel electrophoresis (SDS-PAGE). Polyacrylamide gel electrophoresis was performed in a Tris $0.025 \mathrm{M}$ glycine $0.192 \mathrm{M}$ buffer, $\mathrm{pH}$ 8.3, according to Laemmli (32).

Evaluation of C3 conversion. C3 conversion was measured by two-dimensional antigen-antibody crossed electrophoresis (33) in $1 \%$ agarose with a $0.037 \mathrm{M}$ barbital buffer containing $0.045 \mathrm{M}$ Tris, $0.1 \mathrm{M}$ glycine, and $0.02 \mathrm{M}$ EDTA at $\mathrm{pH}$ 8.6. A voltage of $20 \mathrm{~V} / \mathrm{cm}$ was applied for $1 \mathrm{~h}$ for the first dimension, and $3 \mathrm{~h}$ for the second dimension; $0.5 \%$ anti-C3 was used in the second dimension.

\section{RESULTS}

Capacity of R.A.M. whole serum to stabilize cell-bound $C \overline{4 b 2 a}$ sites. EAC $\overline{14 b 2 a}$, prepared as described in Methods, were mixed with a $1 / 50$ dilution of the patient's serum or normal human serum in DGVBEDTA $0.02 \mathrm{M}$, and incubated at $37^{\circ} \mathrm{C}$; at timed intervals, samples were drawn from the reaction mixture and the residual $\mathrm{C} \overline{4 \mathrm{~b} 2 \mathrm{a}}$ sites revealed as described in Methods.

Fig. 1 shows that $\mathrm{C} \overline{4 \mathrm{~b} 2 \mathrm{a}}$ sites exhibited no decay on cells incubated with R.A.M. serum after $5 \mathrm{~h}$ at $37^{\circ} \mathrm{C}$.

Fig. 2 shows that the stabilizing effect was linearly dose-related to the input of R.A.M. serum when the residual $\mathrm{C} \overline{4 \mathrm{~b} 2 \mathrm{a}}$ sites were evaluated after a $30-\mathrm{min}$ "decay" time at $37^{\circ} \mathrm{C}$.

Purification of the stabilizing factor and its characterization as IgG. All stabilizing activity was found in

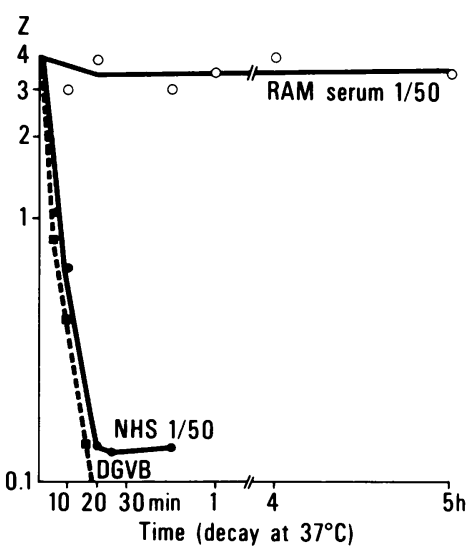

Figure 1 Rate of decay at $37^{\circ} \mathrm{C}$ of EAC $\overline{4 b 2 \mathrm{a}}$ in the presence of R.A.M. or NHS. EAC4b2a in DGVB-EDTA were incubated at $37^{\circ} \mathrm{C}$ in the presence of R.A.M. serum $1 / 50(O)$, NHS $1 / 50(-)$ or DGVB-EDTA alone (ם). At timed intervals, samples were removed and added to $10 \mu \mathrm{l}$ of guinea pig serum to assess residual $\mathrm{C} \overline{4 \mathrm{~b} 2 \mathrm{a}}$ hemolytic activity. $\mathrm{Z}$, average number of hemolytic sites per cell.

the pseudoglobulin fraction of serum and was adsorbed on a CM-cellulose column, pH 5.9, from which it was eluted after application of a salt gradient. The concentrated active fractions were filtered on a precalibrated Sephadex G-200 column, from which it eluted in the early ascending limb of the IgG peak, with an apparent $300,000 \mathrm{~mol}$ wt (Fig. 3). The active pooled fractions were applied to an anti-Fc Sepharose column, on which the activity was absorbed and from which it could be desorbed with a high ionic strength buffer (Table I). The IgG molecules eluted from the anti-Fc immunoabsorbent showed a pattern of migration in SDS-PAGE identical to that of normal IgG molecules; specifically

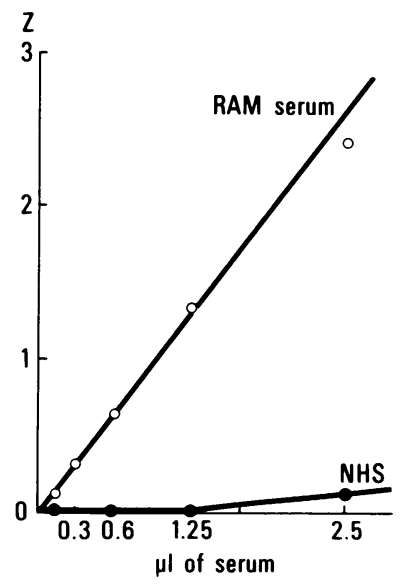

FIGURE 2 Dose-dependent stabilization of EAC $\overline{4 b 2 a}$ by R.A.M. serum. EAC4b2a residual hemolytic activity was measured after $30 \mathrm{~min}$ incubation at $37^{\circ} \mathrm{C}$ in the presence of dilutions of R.A.M. serum (O) or NHS (O) in DGVB-EDTA. $\mathrm{Z}$, average number of hemolytic sites per cell. 


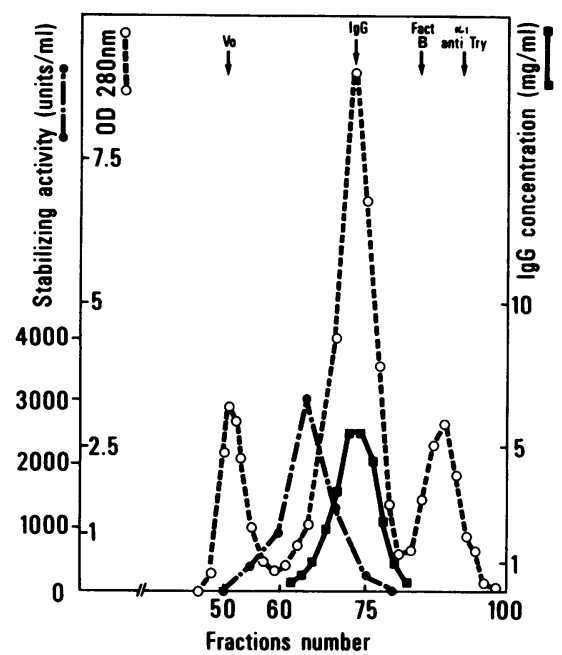

Figure 3 Sephadex G-200 gel filtration of the EAC $\overline{4 b 2 a}$ stabilizing activity. $7 \mathrm{ml}$ of concentrated CM-cellulose active fractions were applied to a $2.5 \times 10-\mathrm{cm}$ Sephadex G-200 column. A description of the EAC $\overline{4 b 2 a}$ stabilizing activity assay and the unit definition are given in Methods. IgG concentration was measured by electroimmunodiffusion. The elution volumes of marker proteins are shown by arrows.

no large component (in excess of $160,000 \mathrm{~mol} \mathrm{wt}$ ) could be seen on the unreduced gels. The apparent incongruence in molecular weight estimations of the stabilizing factor by gel filtration in relation to SDSPAGE will be discussed later. After reduction, this $\mathrm{NF}_{\mathrm{C}}$-enriched IgG fraction (representing $<3 \%$ of the total R.A.M. IgG) showed that in addition to the expected IgG heavy and light chain bands, a third band was apparent (Fig. 4) corresponding to IgG molecules bearing a relatively large heavy chain $(\sim 60,000 \mathrm{~mol} \mathrm{wt})$.
This population comprised $\sim 30 \%$ of the $\mathrm{NF}_{\mathrm{C}}$-enriched fraction and thus $\sim 1 \%$ of the total R.A.M. IgG.

Persistence of the stabilizing activity in $F(a b)_{2}{ }_{2}$ and Fab fragments of IgG. Whether the IgG-associated stabilizing factor in R.A.M. serum behaves like an antibody was assayed by the capacity of $\mathrm{F}(\mathrm{ab}){ }_{2}{ }_{2}$ and $\mathrm{Fab}$ fragments of R.A.M.-IgG to stabilize solid-phase C $\overline{4 b 2 \mathrm{at}}$ sites (Table II).

Upon pepsin treatment, the $\mathrm{C} \overline{4 \mathrm{~b} 2 \mathrm{a}}$ stabilizing activity which was excluded from Sephadex G-100 when undigested, eluted after the void volume, at the same position as $\mathrm{F}(\mathrm{ab})_{2}$ obtained by pepsin digestion of normal IgG. The specific activity of the $F(a b)_{2}$ fragments was $50 \%$ that of the intact parent IgG. However, acid treatment without pepsin also led to an approximate $50 \%$ diminution in stabilizing activity as compared to untreated R.A.M. IgG.

After papain hydrolysis, $\mathbf{N F}_{\mathrm{C}}$ was applied to the anti-Fc gamma Sepharose column. In contrast with the results obtained with undigested $\mathrm{NF}_{\mathrm{C}}$ (vide supra), the stabilizing activity was retrieved in the breakthrough protein peak, indicating that the stabilizing activity resides in the Fab fragment.

Samples of the so purified $F(a b)^{\prime}{ }_{2}$ and $F(a b)$ fragments were run on SDS-PAGE. These preparations gave one unique visible band after coloration, corresponding to the $\mathrm{F}(\mathrm{ab})_{2}{ }_{2}$ and $\mathrm{Fab}$ molecular weight, respectively (not shown).

Specificity of the interaction of $\mathrm{NF}_{C}$ with cell-bound C $\overline{4 b 2 a}$ complex. To study its specificity, $\mathrm{NF}_{\mathrm{C}}$ was added to different complement intermediates: $(a)$ EAC $\overline{14 b 2 a}$ (experimental) and EAC $\overline{14 b}$ (control) cells were incubated with $\mathrm{NF}_{\mathrm{C}}$ for 30 min at $4^{\circ} \mathrm{C}$ and then washed; $\mathrm{C} 2$ was added and the stability of the resulting C $\overline{4 b 2 a}$ sites was assessed as above. Whereas $>90 \%$ of

TABLE I

Elution of the Stabilizing Activity (G-200 Pool) from Anti-IgA and Anti-Fc-IgG Immunoadsorbents

\begin{tabular}{lccr}
\hline & $\begin{array}{c}\text { IgG } \\
\text { concentration* }\end{array}$ & $\begin{array}{c}\text { Stabilizingt } \\
\text { activity }\end{array}$ & Activity \\
\hline & $n m o l$ & $\mu / \mathrm{ml}$ & $\mathrm{nmol} / \mathrm{IgG}$ \\
$\mathrm{NF}_{\mathrm{C}}$ & 13.6 & 1,600 & 118 \\
$\begin{array}{l}\text { Anti-IgA Sepharose } \\
\text { Breakthrough peak }\end{array}$ & 4.3 & 567 & 132 \\
$\begin{array}{l}\text { Salt eluate } \\
\begin{array}{l}\text { Anti-Fc-IgG Sepharose } \\
\text { Breakthrough peak }\end{array}\end{array}$ & 0 & 0 & 0 \\
Salt eluate & 0 & 0 & 0 \\
\hline
\end{tabular}

The Ig fixed on the immunoadsorbent were specifically eluted with $4 \mathrm{M} \mathrm{MgCl}_{2}$, pH 6.8.

* Ig concentrations were measured by electroimmunoassay.

‡ Definition of one stabilizing activity unit is given in the text. 


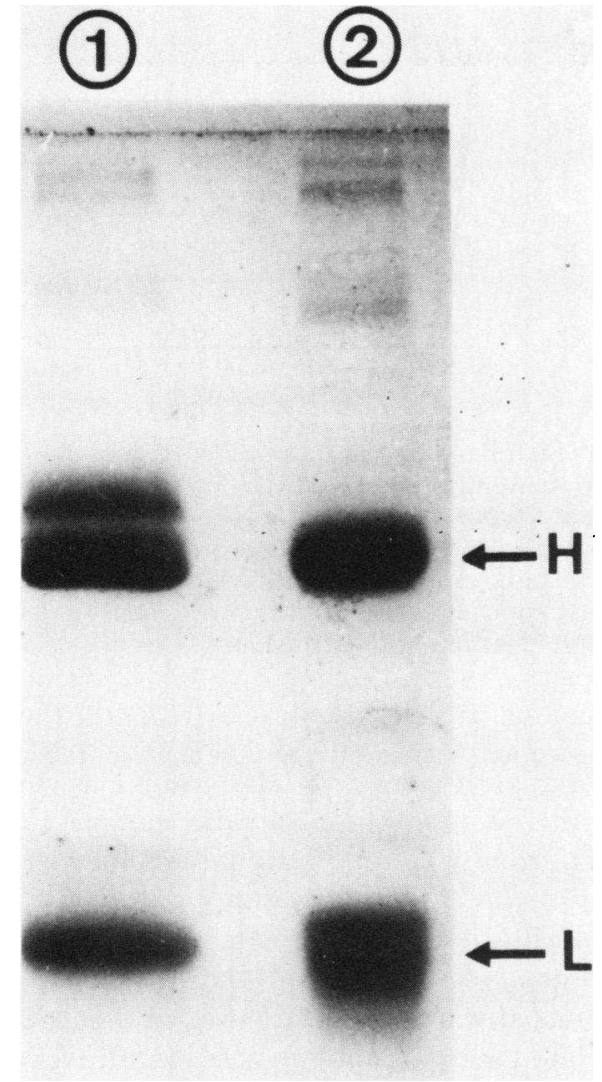

FIGURE 4 SDS-PAGE electrophoresis in $10 \%$ gel of $\mathrm{NF}_{\mathrm{c}}(1)$ and normal IgG (2) after reduction. The positions of normal IgG heavy and light chains are indicated by arrows.

the C $\overline{4 \mathrm{~b} 2 \mathrm{a}}$ sites borne by control cells were lost after decay, no diminution in the number of these sites could be appreciated with the experimental cells. Further- more, when $5 \mu \mathrm{l}$ of $\mathrm{NF}_{\mathrm{C}}(4,000$ stabilizing $\mathrm{U} / \mathrm{ml})$ were incubated with various cellular intermediates, for $5 \mathrm{~min}$ at $30^{\circ} \mathrm{C}$ and $2 \mathrm{~h}$ at $4^{\circ} \mathrm{C}$, the titer of the stabilizing activity was significantly lowered in the supernate of the mixture of $\mathrm{NF}_{\mathrm{C}}$ with EAC $\overline{14 \mathrm{~b} 2 \mathrm{a}}$ but not in that of the mixture of $\mathrm{NF}_{\mathrm{C}}$ with $\mathrm{EA}$ or $\mathrm{EAC} \overline{14 \mathrm{~b}}$ cells. Thus, $\mathrm{NF}_{\mathrm{C}}$ binds specifically to the Cil4b2a complex and not to $\mathrm{C} \overline{14 \mathrm{~b}}$ alone (Table III). (b) $\mathrm{NF}_{\mathrm{C}}$ eluted from the anti-Fc Sepharose column (where it separated from properdin) did not stabilize the alternative pathway $\mathrm{C} 3$ convertase in the $\mathrm{C} \overline{\mathrm{BbB}}$ stabilizing assay (Methods) (Table IV). Conversely, $\mathrm{NF}_{\mathrm{A}}$ did not stabilize cell-bound $\mathrm{C} 42$ sites in our assay system. Thus, $\mathrm{NF}_{\mathrm{C}}$ and $\mathrm{NF}_{\mathrm{A}}$ antibodies do not share their respective specificity for either of the two complement C3 converting enzymes.

Stabilization of fluid-phase C $\overline{4 b 2 a}$ complex prepared from purified classical pathway components. $5 \mu \mathrm{g}$ of $\mathrm{C} 4$ and $10,000 \mathrm{C} 2$ hemolytic units in PBS-Mg 3 $\mathrm{mM}$ were mixed at $37^{\circ} \mathrm{C}$ and $3 \mu \mathrm{g}$ of CIs added. After $5 \mathrm{~min}$ at $37^{\circ} \mathrm{C}, 0.04 \mathrm{M}$ EDTA, and $5 \mu \mathrm{l}$ of NHS-EDTA $20 \mathrm{mM}$ were sequentially added to the mixture which was further incubated for $1 \mathrm{~h}$ at $37^{\circ} \mathrm{C}$. Under these conditions, $80 \%$ of the serum C3 was converted. The fluid-phase C $\overline{4 b 2 a}$ enzyme so created is however labile, with a half-life of about 3-4 min (Fig. 5). When $5 \mathrm{U}$ of $\mathrm{NF}_{\mathrm{C}}$ were present in the mixture of $\mathrm{C} 4, \mathrm{C} 2$, and $\mathrm{C} 1 \mathrm{~s}$, the enzyme converted $100 \%$ of the serum $\mathrm{C} 3$, and no decay was observed after $1 \mathrm{~h}$ at $37^{\circ} \mathrm{C}$. This C3 cleaving activity required each of the components $\mathrm{C} \overline{\mathrm{ls}}, \mathrm{C} 4, \mathrm{C} 2, \mathrm{Mg}$, and $\mathrm{NF}_{\mathrm{C}}$, and did not require other factors. Normal IgG at the same concentration did not prevent the decay of the enzyme.

Lack of C3 activation in NHS incubated with R.A.M. IgG. The incubation of up to $10 \mu \mathrm{g}$ of $\mathrm{NF}_{\mathrm{C}}$ with $10 \mu \mathrm{l}$ of NHS for $2 \mathrm{~h}$ at $37^{\circ} \mathrm{C}$ did not produce any measurable activation of $\mathrm{C} 3$.

TABLE II

Recovery of Stabilizing Activity after Pepsin and Papain Digestion

\begin{tabular}{lccc}
\hline & $\begin{array}{c}\text { Protein } \\
\text { concentration }\end{array}$ & $\begin{array}{c}\text { Stabilizing } \\
\text { activity }\end{array}$ & $\begin{array}{c}\text { Stabilizing } \\
\text { activity }\end{array}$ \\
\hline $\begin{array}{l}n m o l \\
\text { R.A.M. (Fab) } 2\end{array}$ & 10 & $\mu / m l$ & $n m o l$ \\
$\begin{array}{l}\text { Acid-treated R.A.M.-IgG } \\
\text { (pepsin control) }\end{array}$ & 14 & 443 & 44 \\
$\begin{array}{l}\text { R.A.M.-Fab\$ } \\
\text { R.A.M.-IgG }\end{array}$ & 20 & 825 & 59 \\
\hline
\end{tabular}

Proteolysis conditions are described in Methods.

${ }^{*} \mathrm{IgG},(\mathrm{Fab})_{2}$, and Fab concentrations were determined by Folin titration.

$\ddagger(\mathrm{Fab})_{2}$ was purified on Sephadex G-100.

$\S$ Fab fragment was purified by passing through an anti-Fc Sepharose immunoadsorbent. 
TABLE III

Specific Binding of $N F_{C}$ to $C \overline{4 b 2 a}$

\begin{tabular}{cc}
\hline $\begin{array}{c}\text { Cellular intermediates* } \\
\text { preincubated with } \mathrm{NF}_{\mathrm{c}}\end{array}$ & $\begin{array}{c}\text { Residualt } \\
\text { stabilizing activity }\end{array}$ \\
\hline $4,000 \mathrm{U} / \mathrm{ml}$ & $U / m l$ \\
EAC $\overline{14 \mathrm{~b} 2 \mathrm{a}}\left(5 \times 10^{8}\right)$ & 400 \\
EAC $\overline{14 \mathrm{~b} 2 \mathrm{a}}\left(0.75 \times 10^{8}\right)$ & 800 \\
EAC $\overline{14 \mathrm{~b}}\left(5 \times 10^{8}\right)$ & 3,755 \\
EA $\left(5 \times 10^{8}\right)$ & 4,000
\end{tabular}

* The different cellular intermediates were preincubated with $5 \mu \mathrm{l} \mathrm{NF}$ c $(4,000 \mathrm{U} / \mathrm{ml})$ for $5 \mathrm{~min}$ at $37^{\circ} \mathrm{C}$ and $2 \mathrm{~h}$ at $4^{\circ} \mathrm{C}$.

$\$$ The supernates were tested for EAC $\overline{14 \mathrm{~b} 2 \mathrm{a}}$ stabilization as described in Methods.

\section{DISCUSSION}

The results reported in this paper describe a unique factor functionally able to stabilize the normally labile C4b2a enzyme of the classical pathway of complement and identified as the IgG autoantibody to the enzymatic

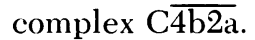

This factor enhances the half-life of cell-bound C $\overline{4 b 2 a}$ sites from 4 to 300 min or even more in our test system (Fig. 1). This enhancing effect is proportional to the amount of the patient's serum used in the assay input (Fig. 2), and is also conferred upon C $\overline{4 b 2 a}$ complexes formed in the fluid phase with purified $\mathrm{C} 4$ and $\mathrm{C} 2$ in the presence of an excess purified Cls (Fig. 5).

Such activity is associated to a serum protein that cannot be distinguished from IgG, according to the following data: (a) On SDS-PAGE it has a size and chain composition compatible with that of an IgG molecule. (b) After pepsin digestion, the stabilizing activity is found in a G-100 fraction containing molecules whose weights are similar to that of a $F(a b)_{2}$ IgG. This was confirmed by SDS-PAGE to which the G-100 pepsin digested active fractions were submitted, showing one single stainable band of an $\sim 100,000$

TABLE IV

Specificity of Nephritic Factors for their Respective C3 Convertase

\begin{tabular}{lc}
\hline & Stabilizing activity \\
\hline & U/n.M IgG \\
$\mathrm{EAC} \overline{14 \mathrm{~b} 2 \mathrm{a}}+\mathrm{NF}_{\mathrm{C}}{ }^{*}$ & 109.5 \\
$\mathrm{EAC} \overline{14 \mathrm{~b} 2 \mathrm{a}}+\mathrm{NF}_{\mathrm{A}}$ & 0 \\
$\mathrm{EAC} \overline{\mathrm{bBb}}+\mathrm{NF}_{\mathrm{C}}$ & 0 \\
$\mathrm{EAC} \overline{\mathrm{bBb}}+\mathrm{NF}_{\mathrm{A}}$ & 376 \\
\hline
\end{tabular}

* IgG fraction from patient R.A.M. purified by affinity chromatography.

\$ IgG preparation from one patient with proven type II glomerulonephritis, purified according to Daha (21).

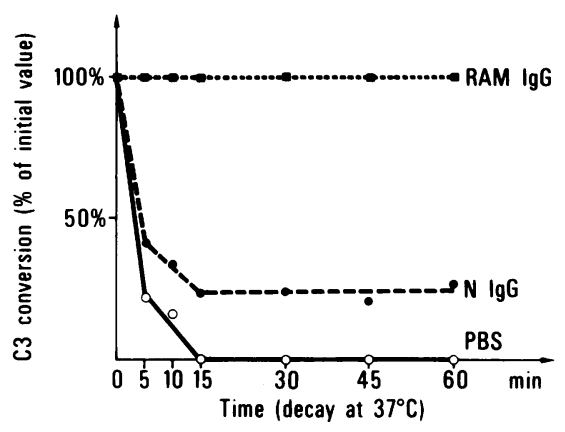

FIgURE 5 Stabilization of fluid-phase C $\overline{4 b 2 a}$ by $N_{\text {c }}$. Decay of $\mathrm{C} \overline{4 \mathrm{~b} 2 \mathrm{a}}$ prepared from purified $\mathrm{C} \overline{\mathrm{Is}}, \mathrm{C} 4$, and $\mathrm{C} 2$ in the presence of PBS $(\bigcirc)$, normal $\operatorname{IgG}(\odot)$, or $\mathrm{NF}_{\mathrm{C}}(\mathbf{\square})$ at $37^{\circ} \mathrm{C}$. After different incubation times at $37^{\circ} \mathrm{C}$, the residual $\mathrm{C} 3$ convertase activity was tested by incubation with NHS-EDTA. The amount of $\mathrm{C} 3$ conversion after $1 \mathrm{~h}$ at $37^{\circ} \mathrm{C}$ was measured by twodimensional electroimmunodiffusion.

mol wt. (c) The stabilizing activity is associated to a material antigenically related to IgG, as shown by the specific adsorption on anti- $\mathrm{Fc}$ gamma immunoadsorbent, from which the activity, together with $\operatorname{IgG}$, could be recovered after appropriate salt elution (Table I). Thus, this stabilizing factor has the physicochemical characteristics of an IgG.

The unusual biological properties of this $\operatorname{IgG}\left(\mathrm{NF}_{\mathrm{C}}\right)$ are associated with the antigen binding site: the pepsin digestion experiment indicate that the activity is associated with the $\mathrm{F}(\mathrm{ab})_{2}$ fragment of IgG. After papain treatment, the activity is linked to a smaller fragment of the size of $\mathrm{Fab}$ no longer reacting with the anti- $\mathrm{F}_{\mathrm{C}}$ immunoadsorbent. That monovalent $\mathrm{Fab}$ fragment of

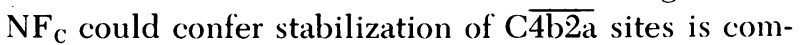
patible with this IgG-like factor acting as an antibody, and indicates that its function requires only one active binding site.

This antibody physically binds to EAC $\overline{14 \mathrm{~b} 2 \mathrm{a}}$, and not to EAC $\overline{14 b}$ cells; it stabilizes the fluid-phase C.3 convertase generated by the reaction of $\mathrm{C} \overline{\mathrm{Is}}$ with purified $\mathrm{C} 4$ and $\mathrm{C} 2$ in the presence of magnesium. Because $\mathrm{C} \overline{1 s}$ has never been shown to be associated to such a fluid-phase C $\overline{4 b 2 a}$ complex, either antigenically or functionally, it is reasonable to assume that the antigenic determinant, specifically recognized by $\mathrm{NF}_{\mathrm{C}}$, is indeed borne by $C \overline{4 b 2 a}$. Finally, because $N_{C}$ has no effect on cell-bound $\mathrm{C} \overline{\mathrm{BbBb}}$ enzyme of the alternative pathway (Table IV), it is distinct from the $\mathrm{NF}_{\mathrm{A}}$ despite their other analogies.

From what is known of $\mathrm{NF}_{\mathrm{A}}$ on the stabilization of the $\mathrm{C} \overline{\mathrm{bBBb}}$ complex, $\mathrm{NF}_{\mathrm{C}}$ could provide this extraordinary functional longevity to the $\mathrm{C} \overline{4 \mathrm{~b} 2 \mathrm{a}}$ complexes by one or both of the following two mechanisms: (a) Prevention of C $\overline{4 \mathrm{~b} 2 \mathrm{a}}$ intrinsic decay dissociation. (b) Inhibition of a speculated regulatory protein of the classical pathway convertase, functionally analogous to 
$\beta 1 \mathrm{H}$. Relevantly it was of interest that $\mathrm{NF}_{\mathrm{C}}$ added to NHS did not lead to C3 conversion. This absence of C3 conversion in the presence of $\mathrm{NF}_{\mathrm{C}}$ in NHS does not support the hypothesis of a "Cl tickover" (34) spontaneously able to generate $\mathrm{C} \overline{4152 \mathrm{a}}$ enzymes in vitro.

The pathophysiology of anticomplement autoimmunisation (immunoconglutinin) is that of a sustained immunogenic presentation of complement components to the immune system $(35,36)$. In our patient the protracted cutaneous lesions (scabies) might have served as foci of "alexination" of superinfecting microorganisms. Alternatively, a sustained intravascular activation of the classical pathway could conceivably lead to anti-C3 convertase autoimmunisation. Indeed circulating immune complexes are regular findings in acute postinfectious glomerulonephritis. As to the pathogenic role of $\mathrm{NF}_{\mathrm{C}}$ in disease, the absence of survey on its occurrence precludes any definite statement on this point. A preliminary report by others, (37) however, suggests that it might be found in lupus erythematosus patients, a disease in which sustained classical pathway activation is known to occur.

The IgG molecules endowed with the autoantibody activity exhibited peculiar physico-chemical characteristics: (a) Their hydrodynamic behaviour on gel filtration (elution as "heavy" IgG) contrasted with a molecular weight not in excess of 160,000 daltons as judged by SDS-PAGE; a discrepancy possibly relatable in terms of molecular configuration and/or carbohydrate content. (b) The stabilizing activity was associated with a population of IgG molecules bearing a heavy chain slightly larger $(60,000 \mathrm{~mol} \mathrm{wt})$ than the average 53,000 mol wt of the major IgG subclasses of man. In keeping with our findings, Scott et al. (17) and Schreiber et al. (19) have reported similar data on the heavy chain of IgG bearing the alternative pathway $\mathrm{NF}_{\mathrm{A}}$. In fact, such physico-chemical characteristics of nephritic factor IgG are quite reminiscent of that of IgG3: (a) The apparently "heavy" molecular weight of IgG3 is related to an unusually carbohydrate-rich hinge region (39). (b) In relation to this carbohydrate contents, the $\gamma 3$-chain has a $60,000-\mathrm{mol}$ wt (40). These analogies suggest but do not prove that $\mathrm{NF}_{\mathrm{C}}$-IgG may be an IgG.3. If this can be positively confirmed, one might interrogate the relative prevalence of IgG:32 as the subclass of immunoglobulin endowed with anticomplement activity $(16,40,41)$ and whether such prevalence also exists in other autoantibody systems.

\section{ACKNOWLEDGMENTS}

We acknowledge the help of M. Netter and M. Lillié in preparing the manuscript.

\footnotetext{
${ }^{2}$ Preliminary data indicates that $\mathrm{NF}_{\mathrm{C}}$ does not bind Staphylococcus aureus protein A.
}

\section{REFERENCES}

1. Müller-Eberhard, H. J., M. J. Polley, and M. A. Calcott. 1967. Formation and functional significance of a molecular complex derived from the second and the fourth component of human complement. J. Exp. Med. 125: $359-380$.

2. Müller-Eberhard, H. J., and O. Götze. 1972. C3 proactivator convertase and its mode of action. J. Exp. Med. 135: $1003-1008$.

3. Daha, M. R., D. T. Fearon, and K. F. Austen. 1976. C3 requirements for the formation of alternative pathway C.5 convertase. J. Immunol. 117: 6.30-634.

4. Vogt, W., G. Schmidt, B. Von Buttlar, and L. Dieminger. 1978. A new function of the activation third component of complement: binding to C5, an essential step for C.5 activation. Immunolog!. 34: 29-40.

5. Medicus, R. G., (). Götze, and H. J. Müller-Eberhard. 1976. Alternative pathway of complement: recruitment of precursor properdin by the labile C.3/C5 convertase and the potentiation of the pathway. J. Exp. Med. 144: 1076-1093.

6. Fujita, T., I. Gigli, and V. Nussenzweig. 1978. Human C4-binding protein. II. Role in proteolysis of $\mathrm{C} 4 \mathrm{~b}$ by C3b-inactivator. J. Exp. Med. 148: 1044-1051.

7. Whaley, K., and S. Ruddy. 1976. Modulation of the alternative complement pathway by $\beta 1 \mathrm{H}$ globulin. J. Exp. Med. 144: $1147-1163$.

8. Weiler, J. M., M. R. Daha, K. F. Austen, and D. T. Fearon. 1976. Control of the amplification convertase of complement by the plasma protein $\beta 1 \mathrm{H}$. Proc. Natl. Acad. Sci. U. S. A. 73: 3268-3272.

9. Lachmann, P. J., and H. J. Müller-Eberhard. 1968. The demonstration in human serum of "conglutinogen activating factor" and its effect on the third component of complement. J. Immunol. 100: 691-698.

10. Ruddy, S., and K. F. Austen. 1971. C3b inactivator of man. II. Fragments produced by $\mathrm{C} 3 \mathrm{~b}$ inactivator cleavage of cell-bound or fluid phase C3b. J. Immunol. 107: $742-750$

11. Cooper, N. R. 1975. Isolation and analysis of the mechanisms of action of an inactivator of $\mathrm{C} 4 \mathrm{~b}$ in normal human serum. J. Exp. Med. 141: 890-903.

12. Spitzer, R. D., E. H. Vallota, J. Forristal, E. Sudora, A. Stitzel, N. C. Davis, and C. D. West. 1969. Serum C'3 lytic system in patients with glomerulonephritis. Science (Wash. D. C.). 164: 436-437.

13. Swainson, C. P., and A. B. Kay. 1976. Mesangiocapillary glomerulonephritis. Some correlations between ultrastructure and complement profiles.J. Immunol. 116: 1738. (Abstr.)

14. Sissons, J. G. P., R. J. West, J. Fallows, D. G. Williams, B. J. Boucher, N. Amos, and D. K. Peters. 1976. The complement abnormalities of lipodistrophy. N. Engl. J. Med. 294: 461-465.

15. Alper, C. A., K. J. Bloch, and F. S. Rosen. 1973. Increased susceptibility in a patient with type II essential hypercatabolism of C3. N. Engl. J. Med. 288: 601-606.

16. Thompson, R. A. 1972. C3 inactivating factor in the serum of a patient with chronic hypocomplementaemic proliferative glomerulonephritis. Immunolog!y. 22: 147-158.

17. Scott, D. M., N. Amos, J. G. P. Sissons, P. J. Lachmann, and D. K. Peters. 1978. The immunoglobulin nature of nephritic factor. Clin. Exp. Immunol. 32: 12-24.

18. Davis, A. E., J. E. Ziegler, E. W. Gelfand, F. S. Rosen, and C. A. Alper. 1977. Heterogeneity of nephritic factor and its identification as an immunoglobulin. Proc. Natl. Acad. Sci. U. S. A. 74: 398()-398.3. 
19. Schreiber, R. D., and H. J. Müller-Eberhard. 1978. Nephritic factor (TA): a homogeneous immunoglobulin directed toward the complex of C3 and Factor B of human complement. J. Immunol. 120: 1796. (Abstr.)

20. Schreiber, E. D., R. G. Medicus, O. Götze, and H. J. Müller-Eberhard. 1975. Properdin- and Nephritic factordependent $\mathrm{C} 3$ convertases: requirement of native $\mathrm{C} 3$ for enzyme formation and the function of bound C3b as properdin receptor. J. Exp. Med. 142: 760-772.

21. Daha, M. H., D. T. Fearon, and K. F. Austen. 1976. C3 nephritic factor $(\mathrm{C} 3 \mathrm{NeF})$ : stabilization of fluid phase and cell-bound alternative pathway convertase. J. Immunol. 116: $1-7$.

22. Leibowitch, J., M. Leveille, and L. Halbwachs. 1979. Description d'une activité enzymatique inhabituelle clivant le 3è composant du complément. C. R. Acad. Sci. Paris. 288: 567-569.

23. Takahashi, K., S. Nagasawa and J. Koyama. 1975. The $\mathrm{NH}_{2}$ terminal sequences of a subunit of the first component of human complement, $\mathrm{Cls}$, and its activated form, $\overline{\mathrm{Cls}}$. FEBS (Fed. Eur. Biochem. Soc.) Lett. 50: 3.30-333.

24. Kerr, M. A., and R. R. Porter. 1978. The purification and properties of the second component of human complement. Biochem. J. 171: 99-107.

25. Lachmann, P. J., M. J. Hobart, and W. P. Aston. 1973. Complement technology. In Handbook of Experimental Immunology. D. M. Weir, editor. 2nd edition. Chapt. 5. Blackwell Scientific Publications Ltd., Oxford.

26. Lesavre, Ph., T. E. Hugli, A. F. Esser, and H. J. Müller-Eberhard. 1979. The alternative pathway C3/C5 convertase. Chemical basis of factor $\mathrm{B}$ activation. $J$. Immunol. 123: 529-534.

27. Avrameas, S, and T. Ternynck. 1969. The cross-linking of proteins with glutaraldehyde and its use for preparation of immunoadsorbants. Immunochemistry. 6: 53-66.

28. Weeke, B. 1968. Quantitative estimation of human immunoglobulins following carbamylation by electrophoresis in antibody-containing agarose. Scand. J. Clin. Lab. Invest. 22: 107-111.

29. Cuatrecasas, P., M. Wilchek and C. B. Anfinsen. 1968. Selective enzyme purification by affinity chromatography. Proc. Natl. Acad. Sci. U. S. A. 61: 636-643.
30. Lachmann, P. J. 1971. The purification of specific antibody as $\mathrm{Fab}_{2}{ }_{2}$ by pepsin digestion of antigen-antibody precipitates, and its application to immunoglobulin and complement antigens. Immunochemistry. 8: 81-87.

31. Swanworth, D. R., and M. W. Turner. 1973. Immunochemical analysis of immunoglobulins and their subunits. In Handbook of Experimental Immunology. D. M. Weir, editor. 2nd edition. Chapt. 10. Blackwell Scientific Publications Ltd., Oxford.

32. Laemmli, U. K. 1970. Cleavage of structural proteins during the assembly of the head of bacteriophage T4. Nature (Lond.). 227: 680-685.

33. Laurell, C. B. 1965. Antigen-antibody crossed electrophoresis. Anal. Biochem. 10: 358-362.

34. Mak, L. W., P. J. Lachmann, and J. Majewki. 1977. The activation of the C3b feedback cycle with human complement components. I. Through the classical pathway. Clin. Exp. Immunol. 30: 200-210.

35. Coombs, R. R. A., A. M. Coombs, and D. G. Ingram. 1961. "The serology of Conglutination and its Relation to Disease". Blackwell Scientific Publications Ltd., Oxford.

36. Williams, R. C., and H. G. Kunkel. 1962. Rheumatoid factor, complement and conglutinin aberrations in patients with subacute bacterial endocarditis. J. Clin. Invest. 41: 666 .

37. Daha, M. R., H. M. Hazevoet, L. A. Van Es, and A. Cats. Stabilization of the classical pathway, $\overline{C 2}$, by a factor $(\mathrm{F}-\overline{42})$ isolated from sera of patients with systemic lupus erythematosus. J. Immunol. In press.

38. Michaelson, T. E., and N. B. Natwig. 1972. The hinge region of IgG3: an extended part of the molecule. FEBS (Fed. Eur. Biochem. Soc.) Lett. 28: 121-124.

39. Patrick, C., and G. Virela. 1978. Isolation of normal human IgG3: identical molecular weight for monoclonal and normal $\gamma 3$-chains. Immunochemistry. 15: 137-139.

40. Davies, A. E., III, E. W. Gelfand, P. M. Schur, F. S. Rosen, and C. A. Alper. 1978. IgG subclass studies of C3 NeF. J. Immunol. 120: 1770. (Abstr.)

41. Fontaine, N., N. Daveau, J.-P. Lebreton, L. Dumouchel, J. P. Vannier, and M. Gaudin. 1980. Evidence that an autoantibody of IgG3 subclass against C3b discloses a C.3NF activity in a patient with partial lipodystrophy and glomerulonephritis. Ann. Immunol. In press. 